\title{
Anti-inflammatory action of pequi oil associated to ultrasound in tendinitis in rats: macroscopic and histological analysis
}

\author{
Luiz Fernando Batista Pereira da Silva ${ }^{(1)}$, Josefa Angélica Cerqueira Poty ${ }^{(1)}$, Marcelino Martins ${ }^{(2)}$, \\ Nayana Pinheiro Machado de Freitas Coelho(2), Antônio Luiz Martins Maia Filho ${ }^{(2)}$, Charllyton Luis Sena da Costa ${ }^{(3)}$
}

\begin{abstract}
Introduction: Repeated overloads of a tendon may give rise to an inflammatory response, called tendinitis, which usually begins suddenly. Researches report that the Brazilian Northeast is common to use the pequi oil (Caryocar Coriaceum wittm) in the treatment of inflammation and other diseases. Objective: To evaluate the anti-inflammatory effect of pequi oil in tendon repair process in rats after induced tendinitis. Methods: 36 male rats were divided into groups: control, ultrasound + oil pequi and pequi oil. To induce tendinitis, it was used a intratendineous injection of collagenase in the right calcaneal tendon. The treatment consisted of daily application of ultrasound + pequi oil or just pequi oil on the tendon. Macroscopic analysis was performed with the pachymeter on 1st, 7th and 14th days. Posteriorly, the rats were sacrificed with an overdose of intravenous barbiturate, then it was dissected and removed the tendon to enable the histological analysis with Hematoxylin \& Eosin (HE). Results: There was a reduction in the number of inflammatory cells in the animals treated for 7 days in the groups UST + pequi oil and pequi oil compared to the control, with $p<0,001$. At 14 days, the group UST + pequi oil showed greater number of fibroblasts than the other groups, with $p<0,01$. Conclusion: The pequi oil accelerated the tendon repair in the animals and the treatment with US + pequi oil was the most effective because it reached good statistical significance in seven and 14 days.
\end{abstract}

Keywords: Physiotherapy. Rehabilitation. Ultrasound. Inflammation. Tendinopathy.

Study conducted at Faculdade Integral Diferencial- FACID Devry -, Teresina (PI), Brazil.

\section{INTRODUCTION}

Repetitive overloads of a tendon, biomechanical or vascular problems may give rise to an inflammatory response, called tendinitis, which usually has a sudden onset. Initially, individuals report a subtle pain in the tendon after an exercise demand, which, when left untreated, also affects their daily activities, thus being able to progress to a degenerative process, predisposing to more serious injuries such as ruptures, unnecessary wear and other sequela $\mathrm{e}^{(1.2)}$.

The use of medicinal plants comes from native knowledge, already being used in several parts of the world, especially in countries that are still developing, where the majority of the poor population can not afford industrialized medicines. The medicinal plants are the raw materials of vegetable origin which have been used to alleviate, prevent or cure diseases or to change their physiological and pathological process both in humans and in animals $s^{(3-5)}$.

In the Brazilian Northeast it is common to use the pequi oil (Caryocar coriaceum Wittm) in the treatment of inflammation and other diseases such as colds and broncho-pulmonary infections, by containing fatty acids in its composition, widely used as healing agents for popular of various culture countries. It also refers to the external use of the oil in small wound dressings, in the form of compresses and physiotherapeutic massages in cases of muscular, rheumatic and bruising pains, because the fatty acids function as a protective barrier against microorganisms, avoid tissue dehydration and have a important immunomodulatory character ${ }^{(6-8)}$.

Physiotherapy is based on the rehabilitation processes with the use of non-invasive techniques, using several resources to achieve satisfactory results in a faster and more efficient way in the consequences of numerous pathological conditions and diseases, especially those of musculoskeletal origin, such as example, tendonitis, which are one of others types of inflammation present in the population ${ }^{(9)}$.

Among the physiotherapeutic techniques for rehabilitation, we highlight the phonophoresis, which is the use of a medicine in the form of gel associated with the transducer of the physiotherapeutic ultrasound device, which differs from the

Corresponding Author: Luiz Fernando Batista Pereira da Silva. Rua Industrial Francisco Castro, 1606, Condomínio Villa do Conde, Casa 04. CEP: $64052-580$. Telefone: (86) 99900-7795. E-mail: luyzfernando2@hotmail.com.

1 Faculdade Integral Diferencial, Teresina (PI), Brazil.

Full list of author information is available at the end of the article.

Financial Support: Faculdade Integral Diferencial (FACID/DEVRY).

Received on: March 17, 2016; Accepted: May 2, 2016 
medical ultrasound because it is used in the rehabilitation of pathologies. Phonophoresis occurs by the preparation and introduction of the substance topically to promote local or systemic effects and the ultrasound facilitates the penetration of these substances, which allows a transcutaneous penetration between 4 and 5 centimeters by increasing somatic pressure. The drugs most used in phonophoresis are anesthetics, the irritants and anti-inflammatory drugs, mainly seeking to achieve pain relief or an anti-inflammatory action ${ }^{(10-11)}$.

Thus, the objective of the present study was to evaluate the anti-inflammatory effect of pequi oil in the process of tendon repair in rats after induced tendinitis.

\section{METHOD}

The research was initiated after submission and approval by the Committee on Ethics in the Use of Animals (CEUA) of the Faculdade Integral Diferencial-FACID/DEVRY, under the protocol number $006 / 2012$, according to the law $n^{\circ} 11.794 / 2008$.

The study was delineated as experimental with a quantitative approach. The field of data collection was the Physiology laboratory of a private higher education institution in the city of Teresina-PI, due to the physical structure being sufficient to carry out the work.

Data collection was conducted from February 2013 to January 2014. The study included 36 males of the Wistar (Rattus norvegicus), from the vivarium of the Faculdade Integral Diferencial-FACID/DeVry, kept from birth to the age of 30 days in a light and dark cycle of 12 hours with feed and water ad libitum, weighing between 200 and $250 \mathrm{~g}$, randomly divided into three groups with 12 animals. The animals were grouped by period according to treatment and analysis of macroscopic and histological data, which followed a pattern of seven and 14 days.

The pequi oil (Caryocar Coriaceum wittm) was commercially purchased from the Teresina-PI Supply Center in February 2013 in the home-made form.

The animals were randomly divided into three groups with 12 animals each according to the treatment: control, Ultrasound+pequi oil and pequi oil. Subsequently, the animals were subdivided into groups $A$ and $B$ with treatment time of seven and 14 days, with six each. Tendonitis was induced in all groups and animals in the control group received no treatment. The injured animals were treated with $0.5 \mathrm{ml}$ of pequi oil for seven and 14 days.

To perform the procedure, the animals were anesthetized intramuscularly with $10 \%$ ketamine hydrochloride $(0.1 \mathrm{~mL} / 100 \mathrm{~g} / \mathrm{kg}$ - dose), combined with the same dose of $2 \%$ xylazine hydrochloride. The rats received a intratendinous injection with $0.10 \mathrm{ml}$ of collagenase ( $10 \mathrm{mg} / \mathrm{ml}$; SIGMA; C6885), dissolved in a sterile phosphate buffered saline solution, in the right calcaneus tendon, using a $30 \mathrm{G}$ needle. Subsequent to the surgical procedure, the rats were submitted to prophylactic use of a wide-spectrum Pentabiotic (Fort Dodge ${ }^{\circledR}$ ) in a single dose of $0.02 \mathrm{~mL}$ per $100 \mathrm{~g}$ of the animal, intramuscularly.

The crushed pequi seeds were macerated with hexane at room temperature for the extraction of the total lipids. This procedure was repeated three times at thirty minute intervals. The extract was subjected to a reduced pressure in a rotary evaporator, and thus, the oil of pequi seeds was obtained.

The saponification was done from $50 \mathrm{~g}$ of the oil with $14 \mathrm{~g}$ of potassium hydroxide $(\mathrm{KOH})$ and $750 \mathrm{~mL}$ of methanol under reflux for 60 minutes. Thereafter, $80 \%$ solvent evaporation occur in a rotary evaporator under reduced pressure. The initial volume was reconstituted with distilled water and extracted with diethyl ether in a separator funnel. The ether phase was concentrated on rotary evaporator under reduced pressure, dried over anhydrous sodium sulfate, washed with distilled water and weighed to determine the percentage of unsaponifiable material present in the oil. The material produced was the unsaponifiable fraction of the oil that was used in the biological tests.

The treatment was started 24 hours after induction of tendinitis. An ultrasound of Ibramed brand, model sonopulse in pulsed mode at $10 \%$ was used, frequency of $1 \mathrm{MHz}$, with an intensity of $0.5 \mathrm{~W} / \mathrm{cm}^{2}$, direct coupling method of oscillatory movements in an ERA of $1 \mathrm{~cm}^{2}$ for three minutes, using $0.5 \mathrm{~mL}$ of pequi oil in each animal, where in the UST+pequi oil group the two techniques were associated, whereas in the pequi oil group, only the oil was applied to the tendon as a treatment. Animals were treated daily for a period of seven and 14 days.

The animals from the UST+pequi oil group, as well as the pequi oil group, were positioned in pronation with the limb in extension, where it facilitated the manipulation of the right calcaneus tendon of the animal for proper treatment.

This protocol followed the literature because, for superficial lesions with small area, it uses the above protocol(12). The device was duly calibrated by a specialized company, before and after the proposed treatment, to verify if there would be no loss of intensity during the treatment.

At the end of the 7 and 14 day cycles, the rats were sacrificed by intravenous application of a barbiturate overdose (Pentobarbital Sodium, 60mg/kg). Then, the dissection and removal of the calcaneus tendon from the right hind paw was performed. Thus, enabling the histological analysis of the tendon with Hematoxylin \& Eosin (HE).

All treatments and readings were performed on the right hind paw of each animal. For the intervention and handling the animals were placed in an anesthetic chamber, manufactured by hand, using Halotane as a volatile anesthetic, thus avoiding their suffering. The animals sacrificed were later taken to a landfill.

For macroscopic analysis, it was necessary to quantify the edema in the region of the experimental lesion, where a metal caliper was used, positioned in the hind paw in the region of the right calcaneal tendon of the animal, with the limb in full 
extension, where the reading was measured in millimeters in the first, seventh and 14th day by the same researcher, in order to avoid changes in the mode of measurement, according to the literature.

The rat achilles tendon was isolated after 7 and 14 days of tendinitis induction. For histological preparation, the tissue was fixed in $10 \%$ formaldehyde for a period of $24 \mathrm{~h}$. Then the piece was dehydrated in alcohol with increasing percentages $(50 \%, 70 \%, 80 \%, 90 \%)$ for periods of $1 \mathrm{~h}$ and finally in alcohol $100 \%$ for $8 \mathrm{~h}$. After dehydration, the specimen was diaphanized in xylol for $4 \mathrm{~h}$, remaining in paraffin for $4 \mathrm{~h}$ in a stove at $58^{\circ} \mathrm{C}$ and then emblocated to perform the histological sections.

The pieces were stained with Hematoxylin Eosin - HE, for later microscopic analysis. The slides were also referred to a pathologist who observed the following characteristics: arrangement of the collagen fibers; neovascularization (absent, mild, medium or severe) and type of inflammatory reaction and predominant cell type: acute (neutrophils), chronic (lymphocytes) and acute-chronic (without neutrophils or lymphocytes predominance).

The anatomical piece of interest was removed with a sterile scalpel, with a margin of one centimeter around the lesion and referred for routine histological procedures. Semi-serial sections with $0.5 \mathrm{~mm}$ were obtained, stained with hematoxylin-eosin (HE), submitted to histological analysis. This was done using a Labomed optical microscope (TCM 400), coupled to a digital camera system NA 0.30.

Three images of different fields were obtained in each slide, per animal, in the $40 \mathrm{X}$ objective: central, right and left margin of the lesion. To count the number of inflammatory cells, the Image ${ }^{\circledR}$ computer program was used in its "cell conter" function.

For qualitative evaluation was analyzed the evolution of tendon repair process for the presence of inflammatory cells, fibroblasts and collagen fibers ${ }^{(13)}$.

The study of the data occurred after histological processing, through the analysis of the inflammatory cells, which were stained in purple and pink through $\mathrm{HE}$.

The data were collected in standardized spreadsheets and organized in the Microsoft Office Excel 2010 program. Subsequently, the data were analyzed from the inferential statistics by variance tests for repeated measures, the One Way ANOVA Test Post Hoc TUKEY. The confidence interval used was $95 \%$ around the mean, and the comparison was made in graphic mode. Statistical analysis was performed using Graph Pad Prism 5.0 software.

\section{RESULTS}

After analysis of the data, it was observed a minimum growth in tendon width from 7th to 14 th day, probably due to human failure at the time of calcaneus tendon diameter measurement of rats, which did not compromise the result of the research, since rats were analyzed in groups, not individually.
In comparison of the tendon width values among the three groups, the ultrasound+pequi oil and oil pequi groups were quite effective in the treatment of inflammation after seven days, with highly significant ( $p<0.001$ ), while the control it was not observed significant improvement in that short period of time, which is due to do not received no intervention, however after 14 days, all groups were able to achieve the same tendon width values, demonstrating that the therapy employed was more efficient at an acute phase when it comes to edema analysis (Figures 1 and 2).

In the analysis of the inflammation by the number of Neutrophils, we observed that in the first seven days there was an increase in the anti-inflammatory effect in the

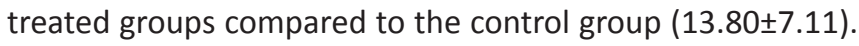
In both the U+Pq.O $(4.22 \pm 2.32 * * *)$ as Pq.O. $\left(2.56 \pm 1.57^{* * *}\right)$ presented statistical significance in the first seven days, which we did not observe after 14 days of treatment [Control

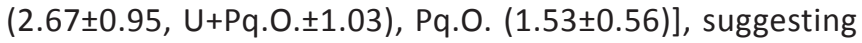
that the organism recovered naturally after 14 days, with a reduction in the number of neutrophils in the Control group, do

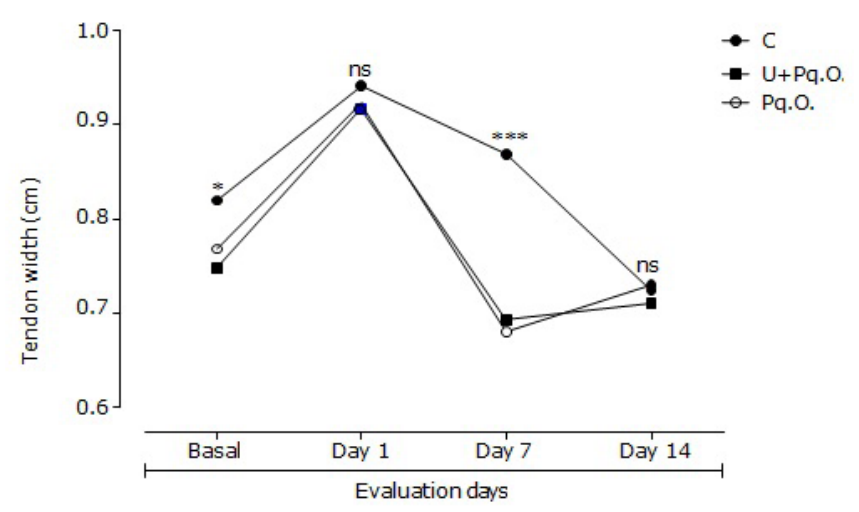

Figure 1: Values of the tendon width evaluated between the values distributed between the time of treatment. Legend: ${ }^{*} p<0,05$ compared to control; $* * * p<0,001$ compared to control; ns (non significant); C (Control); U+Pq.O. (ultrasound + pequi oil); Pq.O. (pequi oil).

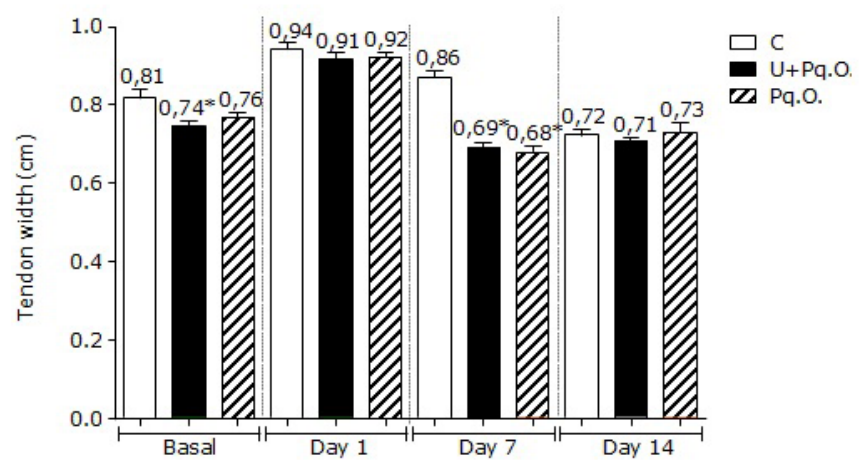

Figure 2: Values of the tendon width evaluated distributed between the time of treatment. Legend: ${ }^{*} p<0,05$ compared to control (C) and groups ultrasond + pequi oil (U+Pq.o.) and Pequi oil (Pq.O.); Mean values shown. 
not presenting statistical difference between groups, ratifying that in the period of seven days both therapies are effective and that after 14 days there is no difference between the groups in this question (Figure 3 ).

In the evaluation of tissue repair through fibroblast cell counting, we observed a restoration of the fiber constitution in the U+ Pq.O. group $\left(3.87 \pm 1.15^{* *}\right)$ in the first seven days, compared to group $C(1.00 \pm 0.33)$, which we did not observe in the Pq.O. group (2.28 \pm 0.93$)$. Regarding the study of the number of fibroblasts at 14 days of the experiment, we observed a numerical difference between the group, but not significant, with the group U+Pq.O. $(4.67 \pm 1.04)$ having a greater numerical representation of fibers compared to groups C (3.07 \pm 0.89$)$ and Pq.O. (2.67 \pm 0.62$)$. This suggests that the activity of pequi oil is efficient, but when associated with ultrasound there is a greater potentiality for tissue reconstitution (Figure 4).

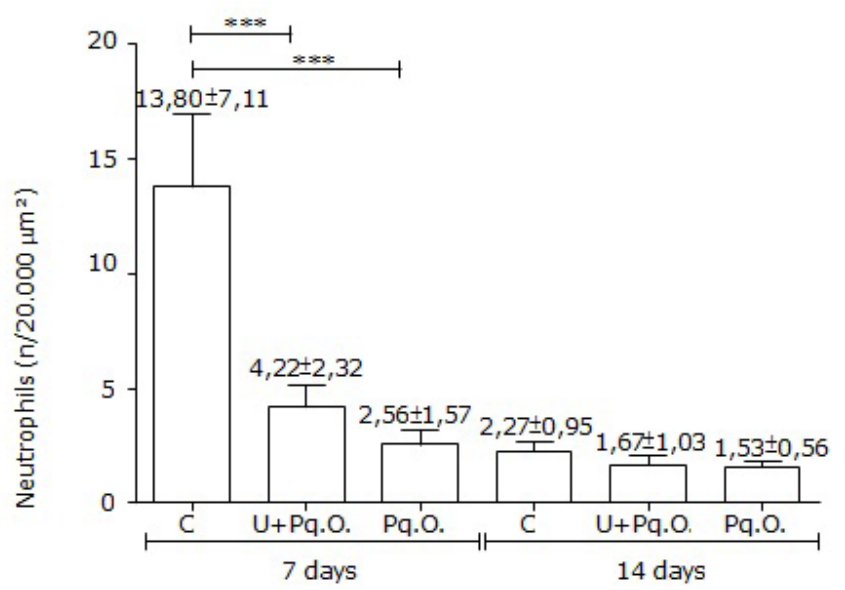

Figure 3: Inflammatory cell values present in the three groups evaluated during the treatment period. Legend: ${ }^{* *} p<0,001$ compared to $C$ (Control); U+Pq.O. (ultrasound + pequi oil) and Pq.O. (pequi oil); $\mu \mathrm{m}^{2}$ (Micrometer squared).

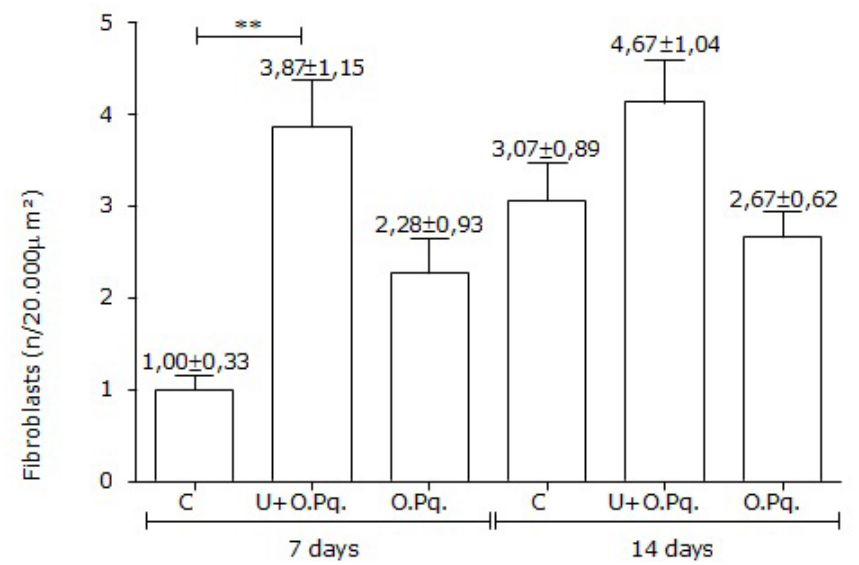

Figure 4: Fibroblast values present in the three groups evaluated during the treatment period. Legend: ${ }^{*} \mathrm{p}<0,01 ; \mathrm{C}$ (control); U+Pq.O. (ultrasound + pequi oil); Pq.O. (pequi oil); $\mu \mathrm{m}^{2}$ (Micrometer squared).

\section{DISCUSSION}

Given the various experimental models that exist, the acute collagenase-induced tendon inflammation model in rats is one of the most used in the study of tendinitis because it resembles the acute inflammation of the tendon in humans with formation of edema and acute destruction of the matrix extracellular, and it is considered an ideal model that allows to investigate molecular and histological changes "in vivo"(14).

In this study, a significant reduction in the size of the damaged area, showing the anti-inflammatory power of Caryocar coriaceum Wittm and therapeutic ultrasound seven and 14 days. In one study ${ }^{(15)}$ it was also carried out the treatment of tendinitis in rats induced, but with the application of fatty material Ovis aries (goat tallow) associated with therapeutic ultrasound of $1 \mathrm{MHz}$, pulsed mode at $10 \%$, intensity of $0.5 \mathrm{Wcm} 2$ during 2 minutes, and it was found that there was a significant anti-inflammatory effect in a period of seven days when compared to the control group, concluding that this technique interferes positively in the tendon healing, as well as the present study that used a similar protocol, differing in substance applied.

In the treatment of tendon lesions, the use of ultrasound is a real possibility therapy, as shown in a study ${ }^{(16)}$, in which the therapeutic ultrasound produced reduction of pain and edema in 21 Wistar rats were divided into control group (CG); Continuous ultrasound (CUG); and pulsed ultrasound (PUG) with injured Achilles tendon, noting that the edema was a decreased earlier for ultrasound in pulsed form, using the same protocol for this research, differing only in the ultrasound cycle, which in this was of $10 \%$ and in the first it was of $20 \%$, which did not significantly interfere in the results of the research, showing that the ultrasound in the pulsed form may be the most effective in this type of therapy.

A research ${ }^{(17)}$ published recently also showed that the pequi oil has positive influence on the healing process of skin lesions in rats, by promoting greater speed tissue repair, by closing faster wounds and observation inflammatory characteristics reduced in the treated group compared to the control group, using 20 Wistar rats (Rattus norvegicus), body weight 300-350g, randomly divided into two groups: GI-control and GII- treated with pequi oil daily topical application of $1 \mathrm{ml}$ and studied in 7 and 14 days, which resembles the findings of this research on the influence that pequi oil has on inflammation, even acting alone, without another therapeutic means of conduction, such as ultrasound.

A study ${ }^{(18)}$ in 25 Wistar rats, divided into three experimental groups (seven and 14 days): $A 7$ and $A 14$, induced tendinitis in the Achilles tendon right without treatment; B7 and B14, induced tendonitis treated with pulsed ultrasound of $1 \mathrm{MHz}$ at $10 \% 0.5 \mathrm{~W} / \mathrm{cm}^{2}$ with neutral gel, and C, control group, showed qualitatively and quantitatively an increase in the number of fibroblasts in seven days, and the collagen fibers at 14 days, for the ultrasound group compared to the 
untreated induced tendonitis group and the control group. These findings confirm the anti-inflammatory power of the US, also found in the present study, which it was able to find it using the associated pequi oil, a fact that further potentiated the tendon repair.

The treatment with pulsed US showed efficacy in tendon regeneration in rats ${ }^{(19)}$, because in 24 animals (Rattus norvegicus albinus), Wistar, male, 24 to 26 weeks of age and weighing between 350 and 450 grams for 11 days treatment after edema induced in the calcaneus tendon, divided in control group (CG) $n=6$, where they did not receive intervention; group 1 (G1) $n=6$, treated for 5 minutes with US in $20 \%$, intensity $0.3 \mathrm{~W} / \mathrm{cm}^{2}$; Group 2 (G2) $\mathrm{n}=6$, treated as the same in the $\mathrm{G} 1$, but with an intensity of $1.5 \mathrm{~W} / \mathrm{cm}^{2}$ and Group $3(\mathrm{G} 3)$ n=6, which received placebo treatment (turned off equipment), it was observed that the $\mathrm{G} 1$ and G2 obtained significance after posttreatment analysis, with a small advantage for $\mathrm{G} 1$, which is in agreement with the results of the present study, which, using a similar protocol, also verified tissue repair efficacy with a larger sample and shorter treatment time with the US.

Another study(20) demonstrated the influence pequi in inflammations, using 15 rats of the species Rattus norvegicus divided into three groups: sham operated (abdominal incision), placebo (pulmonary inflammation without treatment); Treated (pequi oil on acute pulmonary inflammation). It was observed that the treated group at the end of the study had fewer inflammatory cells when compared to the other groups ( $p<0.001)$, suggesting that pequi oil reduces the inflammatory response, even if it is of pulmonary origin, confirming what was seen in this research, which also showed that pequi oil is effective in inflammation, even when applied in isolation on the body, even after analysis of a different pathology and use of a larger sample.

It is observed that many authors agree that phonophoresis brings many benefits, however, many studies are still analyzed only in animals, where, despite their similarity with human, it is suggested that more research in necessary, especially in humans, to verify advantages of this type of therapy.

\section{CONCLUSION}

The pequi oil accelerated the tendon repair process in rats with induced tendinitis, mainly after seven days, but when it was associated with ultrasound, there was an even greater potential for repairing tendonitis, since it was able to reduce the number of inflammatory cells and increase the the number of fibroblasts in seven and 14 days, showing that phonophoresis is an advantageous technique when using pequi oil, which may help not only the physiotherapist on his ducts, but also the population that makes use of alternative therapies.

\section{ACKNOWLEDGMENT}

To the Faculdade Integral Diferencial-FACID/DEVRY for providing full scholarship to completing this study.

\section{AUTHOR'S CONTRIBUTION}

LFBPS contributed specifically in the conception and research design, data collection, analysis and interpretation of data, statistical analysis and writing of the manuscript. JACP was responsible in the research design, data collection, analysis and interpretation of data and writing of the manuscript. MM, NPMFC, ALMMF and CLSC participated in orientation, writing and final review of the article. All authors approved the final version of the manuscript

\section{COMPETING INTERESTS}

The authors have declared that no competing interests exist

\section{AUTHOR DETAILS}

(2) Universidade Estadual do Piauí, Teresina (PI), Brazil.

${ }^{(3)}$ Faculdade Santo Agostinho, Teresina (PI), Brazil.

\section{REFERENCES}

1. Júnior MH, Ferreira MS, Maia ABA, Siena CAF, Techy A. Ultrassonografia no diagnóstico da tendinite e eletroneuromiografia no diagnóstico da neuropatia periférica e da radiculopatia do membro superior - visão do reumatologista. Rev. Bras. Reumatol. 2013; 53(3): 282-7.

2. Martins M, Filho ALMM, Costa CLS, Coelho NPMF, Costa MS, Regiane AC. Ação anti-inflamatória da fração lipídica do Ovis aries associado ao ultrassom terapêutico em modelo experimental de tendinite em ratos (Rattus norvegicus). Rev. Bras. Fisioter. 2011; 15 (4): 297-302.

3. Oliveira GL, Oliveira, AFM, Andrade LHC. Plantas medicinais utilizadas na comunidade urbana de Muribeca, Nordeste do Brasil. Acta Bot. Bras.2010; 24(2): 571-7.

4. Lopes JMDC, Link D. Implantação de um horto didático de plantas bioativas no município de Tupanciretã. Revista Eletrônica em Gestão, Educação e Tecnologia Ambiental. 2011; 2(2): 225-50.

5. Batista JS, Silva AE, Rodrigues CMF, Costa KMFM, Oliveira AF, Paiva ES. et al. Avaliação da atividade cicatrizante do óleo de pequi (Caryocar coriaceum wittm) em feridas cutâneas produzidas experimentalmente em ratos. Arquivo do Instituto Biológico. 2010; 77(3): 441-7.

6. Alves AM, Fernandes DC, Sousa AGO, Naves RV, Naves MMV. Características físicas e nutricionais de pequis oriundos dos estados de Tocantins, Goiás e Minas Gerais. Braz. J. Food Technol. 2014; 17(3): 198203.

7. Oliveira IG, Cartaxo SL, Silva MAP. Plantas medicinais utilizadas na farmacopéia popular em Crato, Juazeiro e Barbalha (Ceará, Brasil). Rev Bras Bioc. 2007; 5 (1):189-91.

8. Santos FS, Santos RF, Dias PP, Júnior LAZ, Tomassoni F. A cultura do Pequi (Caryocar brasiliense Camb.). Acta Iguazu. 2013; 2(3): 46-57.

9. Ricoldy DS, Botura ACA, Oda JY, Takemura OS. Efeito do ultrassom associado ao gel de calêndula sobre a atividade reparadora em lesões musculares experimentais. Acta Scientiarum Health Sciences. 2010; 32(2): 135-40.

10. Filho ALMM, Silva VS, Barros TL, Costa CLS, Maia EPVD, Araújo KS, et al. Efeito do gel da babosa (Aloe barbadensis Mill) associado ao ultrassom em processo inflamatório agudo. Rev. Bras. PI. Med. 2011; 13(2): 146-50.

11. Tassinary JA, Bianchetti P, Rempel C. Avaliação dos efeitos do ultrassom terapêutico sobre a cafeína e verificação da liberação em sistema de difusão vertical. Quím. Nova. 2011; 34(9):1539-43.

12. Martins M, Filho ALMM, Costa CLS, Coelho NPMF, Costa MS, Regiane AC. Ação anti-inflamatória da fração lipídica do Ovis aries associado ao ultrassom terapêutico em modelo experimental de tendinite em ratos (Rattus norvegicus). Rev. Bras. Fisioter. 2011; 15 (4): 297-302. 
13. Coelho NPMF, Nogueira VC, Cardoso MAC; Lopes LS, Nascimento PP; Rocha ES, Silva CLP, Arisawa EAL. Cenostigma macrophyllum Tul. on the healing of skin wounds in rats with Diabetes mellitus. Acta Cir. Bras. 2013; 28(8): 594-600.

14. Lake SP, Ansorge HL, Soslowsky LJ. Animal models of tendinopathy. Disabil Rehabil. 2008; 30(22):1530-41.

15. Martins M, Filho ALMM, Costa CLS, Coelho NPMF, Costa MS, Carvalho RA. Ação anti-inflamatória da fração lipídica do Ovis aries associado ao ultrassom terapêutico em modelo experimental de tendinite em ratos. (Rattus norvegicus). Rev. Bras. Fisioter. 2011; 15 (4): 297-302.

16. Silva JMN, Carvalho JP, Jesus MJM, Arisawa EALS, Martin AA, Sá HP, Silva JF. Estudo da ação do ultrassom terapêutico em modelo experimental de tendinite em ratos Wistar. ConScientia e Saúde. 2010; 9 (4): 625-32.
17. Bezerra NKMS, Barros TL, Coelho NPMF. A ação do óleo de pequi (Caryocar brasiliense) no processo cicatricial de lesões cutâneas em ratos. Rev. Bras. PI. Med.2015; 17(4 supl. II): 875-80.

18. Silva JMN, Carvalho JP, Moura Júnior MJ, Arisawa EALS, Martin AA, Sá HP, Silva JF. Estudo da ação do ultrassom terapêutico em modelo experimental de tendinite em ratos Wistar. ConScientia e Saúde. 2010; 9 (4): 625-32.

19. Frasson NFV, Taciro C, Parizotto NA. Análise nanoestrutural da ação do ultra-som terapêutico sobre o processo de regeneração do tendão de ratos. Fisioter. Pesqui. 2009;16(3): 198-204.

20. Sousa TC, Maia Filho ALM, Araújo KS, Lopes LS, Silva HR, Rodrigues JS, Costa CLS. Anti-inflammatory effect of pequi oil (Caryocar brasiliense) in Acute Respiratory Distress Syndrome. J Med Biomed App Sc. 2014; 1(10):1. 